\title{
Accelerated immune senescence in HIV infection
}

\author{
Victor Appay \\ From $16^{\text {th }}$ International Symposium on HIV and Emerging Infectious Diseases \\ Marseille, France. 24-26 March 2010
}

\begin{abstract}
Aim
The prospect that immune activation or inflammation may be directly related to the increased incidence in HIV infected donors of manifestations that are reminiscent of the human aging process (i.e. cardiovascular disease, malignancies, osteoporosis, cognitive impairment, depression and frailty) is raising increasing concerns. On the immunological side, in addition to promoting viral replication as well as $\mathrm{CD}_{4}^{+} \mathrm{T}$ cell apoptosis, HIV associated immune activation may also lead to an accelerated decline of immune competence resembling the phenomenon of immunosenescence. Our aim is to explore further the potential relationship between immune activation, HIV disease progression and immunosenescence.
\end{abstract}

\section{Materials and methods}

We performed a comparative analysis of immunologic markers in different groups of HIV infected donors and healthy controls. The initial investigation of blood lymphocyte populations led us rapidly to turn our attention onto the lymphocyte primary immune resources, i.e. the $\mathrm{CD}_{34}{ }^{+}$hematopoietic progenitor cells (studied directly from the blood of patients).

\section{Results}

Human aging and HIV-1 infection exhibit a number of parallels with regards to immunological attributes, that are evocative of premature immunosenescence in HIV-1 infected patients and reflect a reduced production of lymphocytes. Analyses of $\mathrm{CD} 34^{+}$hematopoietic progenitor cell number, phenotype and clonogenic potential underline a manifest impairment of primary immune resources with age or HIV-1 infection. Systemic immune activation emerges as a major correlate of altered lymphopoiesis, which can be partially reversed with prolonged antiretroviral therapy. Poor $\mathrm{CD}_{4}^{+} \mathrm{T}$ cell count

\footnotetext{
Infections and Immunity, INSERM UMR S 945, Faculté de Médicine, Hôpital
} Pitié-Salpétrière, 91 Bd de l'Hôpital, 75013 Paris, France recovery despite successful virological response on antiretroviral treatment is associated with persistent damage to the lymphopoietic system.

\section{Discussion}

Our findings provide new insights into the consequences of persistent immune activation in HIV-1 infection, and demonstrate the importance of primary hematopoietic resources in HIV pathogenesis and the response to antiretroviral treatments, but also more generally in the development of immunosenescence.

Published: 11 May 2010

doi:10.1186/1742-4690-7-S1-I30

Cite this article as: Appay: Accelerated immune senescence in HIV infection. Retrovirology 2010 7(Suppl 1):130.

Submit your next manuscript to BioMed Central and take full advantage of:

- Convenient online submission

- Thorough peer review

- No space constraints or color figure charges

- Immediate publication on acceptance

- Inclusion in PubMed, CAS, Scopus and Google Scholar

- Research which is freely available for redistribution

Submit your manuscript at www.biomedcentral.com/submit 